\title{
FILOSOFIS KEBENARAN FIKSI SEBAGAI PENGEMBANGAN INTELEGENSI BAGI KEHIDUPAN INDIVIDU MANUSIA
}

\author{
Wahyudin \\ Institut Agama Islam Negeri (IAIN) Metro \\ Ywah996@gmail.com \\ Rahmah Dwi Nopryana \\ Institut Agama Islam Negeri (IAIN) Metro \\ asmashafira@gmail.com
}

\begin{abstract}
The study of intelligence development, as a form of analyzing the intelligence of creativity in revealing objects and trying to find specific, unique things contained in fiction. Changes in the way of thinking intelligence in a fictional truth is a discourse to express a pattern and story line with an understanding. Understanding of intelligence by distinguishing, guessing, then explaining, which is in fiction. The problem of literary works called fiction is a work that tells something that did not really happen. There is a difference of opinion in a work of fiction because it is not in accordance with his views but, intellectually and academically, the truth is less acceptable. The theory used to uncover the phenomenon is based on theory, Utami Munandar that, by way of divergent thinking. Methodology by using critical analysis in an effort to unravel, philosophically discourse of the truth of fiction by using intelligence as a logical reasoning power to find out the harmony in fiction. The results of the study found that, philosophical truth fiction can change individuals able to imagine, understand the situation, experience, and understanding. The ability of individual intelligence will increase after reading fiction based on the ability of intellectual imagination possessed. The conception is based on the development of intelligent divergent ways of thinking that is spread which is also called creative imaginative thinking an ability to provide various answers based on the information provided, with an emphasis on diversity, number and suitability.
\end{abstract}

Keywoard: Intelligence, Philosophy, Fiction and Individual Development 


\section{A. Pendahuluan}

Kebutuhan akan intelegensi sangat penting dalam pengembangnann kreasi manusia, karena intelegensi akan mempengaruhi pola kehidupan sehari hari antara satu orang dengan orang lain dan yang akan menentukan berfikir manusia untuk menawarkan sebuah hasil karya manusia. Alangkah sebaiknya jika persoalan intelegensi tersebut di bimbing dan diarahkan sejak dini pada mansuia, karena pada manusia peran intelegensi masih bisa di bimbing dan diarahkan serta dibina. Konsep tersebut akan mempengaruhi pengembangan pola piker manusia dalam kehidupannya.

Pengembangan inteligensi, bertugas untuk menyelidiki kehidupan yang di hadapi berusaha menemukan hal hal yang khusus, unik yang terdapat dalam diri manusia yang sedang berkembang. Inteligensi sangat penting bagi pemahaman diri sendiri dan pemahaman terhadap kehidupan yang dihadapinya. Sikap pandangan hidup manusia sangat diperlukan, yang dapat diproyeksikan pada saat sekarang maupun masa mendatang. ${ }^{1}$

Dengan mengetahui inteligensi tentunya menuju perubahan cara berfikir dalam kehidupan sehari hari, dalam berkomunikasi terhadap terhadap apa yang dipahami, inteligensi itu akan mempengaruhi pengembangan naratif bagi kehidupan manusia. Inteligensi akan ikut menentukan sesuatu keadaan dari individu pada suwaktu waktu sebagai akibat dari stimulus yang melingkupinya. Kalau keadan inteligensi telah begitu melampui daya nalar akan membentuk suatu hubungan-hubungan akan meningkatkan sebuah pengetahuan manusia. ${ }^{2}$

Antara intelegensi dan sebuah kebenaran fiksi merupakan wacana dalam dua sisi yang berbeda. Fiksi mengungkapkan sebuah pola dan alur cerita, sedangkan inteleginsi berkaitan dengan akal fikiran dan kecerdasan. Setiap individu yang memiliki intelegensi yang tinggi dia akan memiliki prestasi yang membanggakan, dan dengan prestasi yang dimilikinya akan

1 Hasan Langgulung, Prof. DR., Asas Asas Pendidikan Islam, Al Hgusna Zikra, Jakarta, 2002. h. 16

2 Bimo Walgito, Drs.H. Psikologi Umum, Fakultas Psikologi UGM, Yogyakarta, 1981. h. 135 
lebih mudah meraih keberhasilan. ${ }^{3}$ Zuchdi menjelaskan bahwa pemahaman (comprehension) adalah bagaimana seseorang dengan membedakan, menduga (estimates), kemudian menerangkan, dan menggeneralisasikan, berupa memberikan contoh, serta memperkirakan. Atas dasar pemahaman tersebut untuk dapat membuktikan bahwa anak itu memahami hubungan antara fakta-fakta dengan konsep. Begitu pula dengan pemahaman unsur intrinsik dalam fiksi. Seseorang yang akan memahami unsur pembangun fiksi dituntut untuk dapat mengungkapkan fakta-fakta serta sarana yang ada dalam sebuah cerita. ${ }^{4}$

Bidang Spesifik psikologi sangat besar artinya didalam menyelidiki kehidupan manusia sebagai obyeknya, termasuk pengembanagan inteligensi anak, banyak pakar mengemukakan pendapatnya mengenai aspek-aspek aktivitas manusia. Psychologi is the scientific studies of the individual activities relation to the environtmen (Ilmu jiwa adalah suatu ilmu pengetahuan yang mempelajari tentang aktivitas jiwa atau tingkah laku manusia dalam hubungannya dengan tindakan. ${ }^{5}$ Juga pendapat yang dikemukakan oleh Wilhem Wund (1832-1920) memandang bahwa Psikologi sebagai ilmu yang menyelidiki pengalaman pengalaman yang timbul dalam diri manusia seperti perasaan, panca indera merasa (Feling) fikiran dan kehendak. ${ }^{6}$

Yang menjadi permasalah pada kajian ini, bahwa karya sastra yang disebut fiksi merupakan suatu karya yang menceritakan sesuatu yang tidak terjadi sungguh-sungguh sehingga tidak perlu mencari kebenaranya di dunia realitas. Sebagai karya imajiner, fiksi menawarkan berbagai permasalahan perbedaan pendapat dalam hidup dan kehidupannya. Pengarang produk fiksi telah menghayati berbagai permasalahan tersebut dengan penuh kesungguhan. Pengarang yang kemudian mengungkapkannya kembali melalui sarana fiksi sesuai dengan

3 Syaiful Bahri, Psikologi, Rineka Cipta: Jakarta, 2011, h. 135

4 Zuchdi, D, Strategi Meningkatkan Kemampuan Membaca Peningkatan Komprehensi. UNY Press: Yogyakarta, 2008, h. 73

${ }^{5}$ Woodworth, Robert S And Marquis D.G, Psikologi, Henry Hold and Company New York, 1957. h. 56

${ }^{6}$ Ahmad Fauzi. Drs.H, Psikologi Umum, (Bandung: Pustaka Setia, 1999), h. 19 
pandangannya namun secara intelektual dan akedemik kurang dapat diterima kebenarannya.

Teori yang digunakan untuk mengungkap fenomena tersebut berdasarkan teori, Utami Munandar bahwa, dengan cara berpikir divergen (menyebar) (yang juga disebut berpikir kreatif) adalah kemampuan memberikan bermacam-macam jawaban berdasarkan informasi yang diberikan, dengan penekanan pada keragaman, jumlah dan kesesuaian. ${ }^{7}$

Pada hakekatnya intelegensi seseorang pada kehidupan sehari hari selalu disertai dengan perasaan dan gagasan tertentu dan telah di warnai oleh unsur-unsur yang sangat vareatif. Warna vareatif kadang-kadang kuat dan kadang kadang lemah atau samar samar saja. Dalam hal efektif fareatif yang kuat maka perasaan-perasaan akan sampai pada gagasan, dan bermacam macam efektifitas. 8

Berbagai adanya permasalahan filosofis kebenaran fiksi akan terungkap dengan menganalisis dalam pandang sudut pemikiran mendalam dengan tidak mengkanter fiksi bahwa fiksi hanya sebuah karangan belaka yang tidak ada hubungan dalam kehidupan dunia nyata. Memahami fenomena tersebut suatu kebenaran bersifat relative dengan dengan didasari oleh pembuktian argumen-argumen yang ditemukan untuk memperkuat tingkat kebenaran berikutnya. Sebuah kebenaran fiksi tidak akan terlepaas dari daya fikir divergen, nalar, intelektual manusia secara psikologis sebuah fenomena fiksi tersebut akan mempengaruhi sebuah pengembangan inteligensi walaupun kedua statemen tersebut berjauhan namun akan selalu berdekatan

\section{B. Metode}

Jenis penelitian ini adalah penelitian kepustakaan dan bersifat deskriptif kualitatif filosofis. Metode pendekatannya analisis kritis oleh karena penelitian ini berhubungan secara filosofis atau kefilsafatan tidak lepas dari objek material dan objek forma. Penelitian perpustakaan tidak hanya membaca dan

7Utami Munandar, Pengembangan Kreativitas Anak Berbakat, (Jakarta: Rineka Cipta, 1999), h. 13

8 Ibid, h. 54 
merekam literatur atau buku seperti yang sering dipahami oleh para peneliti, atau penulis. Apa yang disebut penelitian perpustakaan adalah serangkaian kegiatan yang berkaitan diarahkan pada pencarian dan informasi melalui perpustakaan, media cetak online dan internet. ${ }^{9}$ Dokumen-dokumen tersebut berupa tulisan, foto, budaya, nilai-nilai, norma, gambar, dokumen elektronik yang mendukung proses penulisan ilmiah akademik. ${ }^{10}$ Berbagai literatur sebagai catatan yang berkaitan dengan masalah yang harus diungkap. ${ }^{11}$ Deskriptif kualitatif filosofis, berusaha menggambarkan gejala, peristiwa, dan berfokus pada data untuk menemukan kebenaran.12 Penulis dalam mengungkap data berdasarkan literatur melalui analisis kritis. ${ }^{13}$ Dan berupaya mendalami dan memahami realitas topik permasalahan. ${ }^{14}$ Objek materialnya adalah sasaran material yang diselidiki, kebendaan yang bersifat non materi dan materi murni. Sedangkan objek forma adalah cara pandang, sudut pandang suatu paradigma pemikiran. ${ }^{15}$ Adapun objek materianya dalam penelitian ini adalah ketauhidan dan objek formalnya filosofis kritik atas aktivitas teoritis. Analisis kritis dalam rangka menguji pemikiran dan memahami isi ajaran serta mengajukan kritik terhadapnya. ${ }^{16}$ Metode kritis sebagaimana yang di ungkapkan Plato dalam dialog secara kritis untuk menemukan kebenaran. ${ }^{17}$ Analisis Kritis dengan perincian dan pendapat dengan

${ }^{9}$ Kaelan, Metodologi Penelitian Kualitatif bidang Filsafat, (Yogyakarta: Paradigma, 2006), h. 139

10 Sugiyono, Metode Penelitian Kuantitatif, Kualitatif, (Bandung: Alfabeta, 2009), h. 83

11Nazir, Metode Penelitian Kualitatif, (Jakarta: Ghalia Indonesia, 1988), h. 57

12 Noor, J., Metodologi Penelitian Skripsi, Tesis, Desertasi, dan Karya Ilmiah, Jakarta: Kencana, 2011), h. 31

${ }^{13}$ Kuswarno, Engkus, Metodelogi Penelitian, Konsepsi, Pedoman dan Contoh Penelitian, (Bandung: Widia Padjajaran, 2009), h.22

${ }^{14}$ Haris, Herdiansyah, 2012. Metodologi Penelitian Kualitatif Untuk Ilmu-Ilmu Sosial, (Jakarta Selatan: Salemba Humanika, 2012), h. 37

15 Soetriono dan SRDm Rita Hanafi, Filsafat Ilmu dan Metodologi Penelitian, (Yogyakarta: Andi offset, 2007), h. 13

16Bakker, Anton dan Achmad Charris Zuberi, Metodologi Penelitian Filsafat, (Yogyakarta: Kanisisus, 1990), h. 110

17Bakker, Anton, Metode-Metode Filsafat, (Jakarta, Ghalia Indonesia, 1984), h. 25 
menegenai pertanyaan-pertanyaan secara terus menerus sampai kepada hakikat yang di tanyakan. ${ }^{18}$ Analisis kritis dalam upaya menganalisis, secara filosofis wacana sebuah kebenaran fiksi dan inteleginsi berseberangan, kontradisksi bertolak belakang atau adanya keselarasan dan berkesinambungan.

\section{Pembahasan}

\section{a. Filosofis Kenanaran Fiksi}

Cerita fiksi sebagai aktivitas memahami karya imajinasi yang menampilkan keadaan dunia dan narasi antar manusia. Cerita fiksi di kalangan masyarakat kini semakin positif. Berbagai kisah rekaan dan karangan dari imajinasi penulis, kini menjadi salah satu genre yang banyak diminati oleh pembaca. Cerita fiksi merupakan suatu usaha melepaskan pikiran dari kesulitan hidup sehari-hari dikarenakan fiksi bersifat menghibur. Beberapa buku fiksi memberikan gambaran yang tenang, jelas, realitas tentang watak manusia, dan keadaan pada suatu masa atau tempat.

Secara garis besar karya sastra terbagi dua bagian, karya sastra nonfiksi dan fiksi. Karya sastra nofiksi sebagai karya sastra yang himpun berdasarkan kajian keilmuan dan pengalaman dan penulisan buku suatu penyempurnaan buku yang telah ada, sedangkan karya sastra fiksi yaitu cerita rekaan atau cerita khayalan. Karya fiksi sebagai bentuk karya naratif yang isinya tidak menyarankan pada kebenaran sejarah. ${ }^{19}$ Pada sisi lain yang dikemukakan oleh Nurgiyantoro, fiksi suatu karya dapat diartikan sebagai prosa naratif yang bersifat imajinatif, namun biasanya masuk akal dan mengandung kebenaran yang mendramatisasikan hubungan-hubungan antar manusia.

Nurgiyantoro mengemukakan hal ini berdasarkan pengalaman dan pengamatannya terhadap kehidupan. Karya fiksi dilakukan secara selektif dan dibentuk sesuai dengan

${ }^{18 K a t t s o f, ~ O . ~ L o u i s, ~ P e n g a n t a r ~ F i l s a f a t, ~(Y o g y a k a r t a: ~ T i a r a ~ W a c a n a ~}$ Yogya,1996), p.18. Judul Asli: Elements of Philosophy, North Carolina University U.S.A. The Ronald Press Company New York. Alih Bahasa Soejono Soemargono.

19 Nurgiyantoro, Burhan. 2010. Teori Pengkajian Fiksi, (Yogyakarta: Gajah Mada University Press, 2010), h. 2 
tujuannya sekaligus memasukkan unsur hiburan dan penerangan terhadap pengalaman kehidupan manusia. ${ }^{20}$ Fiksi suatu karya, oleh karena itu, merupakan sebuah cerita, karenanya terkandung juga dalamnya tujuan memberikan hiburan. Membaca sebuah karangan fiktif berarti menikmati cerita, menghibur diri untuk memperoleh kepuasan batin. ${ }^{21}$

H. B. Jassin berpendapat yang dikemukakan oleh Faruk bahwa cerita fiksi mengenal salah satu episode dalam kehidupan manusia, suatu kejadian yang luar biasa dalam kehidupan manusia, sebuah krisis yang memungkinkan terjadinya perubahan nasib pada manusia dalam lingkungannya. ${ }^{22}$ Fiksi merupakan jenis prosa yang mengandung unsur tokoh, alur, latar rekaan yang menggelarkan kehidupan manusia atas dasar sudut pandang pengarang, dan mengandung nilai hidup, diolah dengan teknik kisahan dan ragaan yang menjadi dasar konvensi para penulis dan pembaca. ${ }^{23}$

Fiksi menurut Altenbernd dan Lewis dapat diartikan sebagai prosa naratif yang bersifat imajinatif, tetapi biasanya masuk akal dan mengandung kebenaran yang mendramatisasi hubungan-hubungan antar manusia. ${ }^{24}$ Pengarang mengemukakan hal itu berdasarkan pengalaman dan pengamatannya terhadap kehidupan. Namun, hal itu dilakukan secara selektif dan dibentuk sesuai dengan tujuannya yang sekaligus memasukkan unsur hubungan dengan penerangan terhadap pengalaman kehidupan manusia.

${ }^{20}$ Nurgiyantoro, Burhan, Teori Pengkajian Fiksi, (Yogyakarta: Gadjah Mada University Press, 2009), h. 3

21 Nurgiyantoro, Burhan. 2013. Sastra Anak: Pengantar Pemahaman Dunia Anak. (Yogyakarta: Gadjah Mada University Press, 2013), h. 35

22 Faruk, Pengantar Sosiologi Sastra. (Yogyakarta: Pustaka Pelajar, 1999), h. 262

${ }^{23}$ Purba, Antilan, Sastra Indonesia Kontemporer, (Yogyakarta: graha Ilmu, 2010), h. 63

${ }^{24}$ Altenbernd, Lynn dan Lewis. 1966. A Handbook for The Study of Poetry, (New York: Macmillan, 1966), h. 14 
Fiksi juga dapat membantu kita dalam menyelami jiwa kita sendiri dan menelaah jiwa dan tingkah laku orang lain. Buku fiksi yang baik penting sekali dalam kehidupan manusia karna dapat memberikan hiburan, ketentraman, ketenangan serta pengetahuan Nurgiantoro berpendapat fiksi merupakan sebuah cerita yang di dalamnya memberikan hiburan kepada pembaca di samping adanya tujuan estetik. Membaca sebuah karya fiksi seperti menikmati cerita untuk menghibur diri memperoleh kepuasan batin. Daya tarik tersebut yang akan memotivasi orang untuk membacanya sekaligus secara tidak langsung dapat belajar, merasakan, menghayati berbagai permasalahan kehidupan yang ditawarkan pengarang. ${ }^{25}$

Berdasarkan analisis tersebut dapat dikemukakan bahwa karya fiksi yang sebagian bertemakan kehidupan, namun sangat digemari dan sangat berpengaruh dalam pembentukan inteligensi pada manusia, individu, anak-anak di usia remaja yang dalam masa-masa mencari identitas. Karya fiksi tersebut memberikan inspirasi bagi inteligensi yang devergen menyebar meluas dalam diri yang membacanya, sehinga akan mempengaruhi daya fikir seseorang.

Di dalam cerita fiksi mengandung aktivitas memahami karya imajinasi yang menampilkan keadaan dunia dan relasi antar manusia. Sebuah cerita fiksi akan meningkatkan kemampuan kognitif dan afektif bagi para pembaca dengan melalui pemikiran dan perasaan dalam cerita yang di jabarkan. Pembaca akan membayangkan dan menempatkan diri sebagai tokoh atau karakter pada saat membaca cerita fiksi. ${ }^{26}$

Bagi setiap person yang membaca cerita fiksi akan mengolah stimulus berupa pemikiran dan emosi tokoh sehingga individu cenderung memahami dan mengaitkan dengan kejadian dan relasi dalam kehidupan sehari-hari. Cerita fiksi akan menampilkan berbagai masalah kehidupan manusia serta interaksinya dengan sesama manusia. Selain itu, cerita fiksi membuat kehidupan individu akan mampu

${ }^{25}$ Nurgiyantoro, 2009, h. 5

26 Stanton, R, Teori Fiksi. Yogyakarta: Pustaka Pelajar, 2007), h. 67 
berimajinasi, memahami situasi, pengalaman, dan emosi orang lain. Kemampuan empati individu akan meningkat setelah membaca cerita fiksi sehingga kemampuana imajinasi intelektual akan meningkat.

Mar, Oatley, dan Peterson menyatakan bahwa aktivitas fiction reading membantu seseorang membangun pengetahuan mengenai cara merespons emosi orang lain dalam situasi sosial. ${ }^{27}$ Cerita fiksi mudah dipahami karena sesuai dengan pengalaman sehari-hari pembaca. ${ }^{28}$ Kata-kata dalam cerita fiksi mengaktifkan proses kognitif individu untuk mengaitkan dengan kejadian dalam kehidupan nyata (Zwaan, 2004).29 Mar (dalam Hojat, 2009) menyebutkan bahwa cerita fiksi meningkatkan kemampuan berpikir imajinatif sehingga pembaca membayangkan aktivitas, pikiran, dan perasaan yang dialami tokoh. ${ }^{30}$

Tiap individu secara kodrati membawa variasi dan irama perkembangannya sendiri, perlu untuk diketahui setiap individu tersebut akan menghadapi perkembangan pada tingkat kreativitas dan naratifnya. Individu hendaknya bersikap tenang sambil terus mengikuti pertumbuhan itu, agar pertumbuhan itu sendiri terhindar dari gangguan apapun yang tentu saja akan merugikan. Para ahli yang mengikuti aliran asosiasi berpendapat bahwa hakekatnya perkembangan adalah proses asosiasi, menurut aliran ini asosiasi hal yang primer adalah bagian-bagian, sedangkan keseluruhan adalah skunder. ${ }^{31}$

27 Oatley, K. Mar dan Peterson, Why fiction may be twice as true as fact: fiction as cognitive and emotional simulation. Journal, Review of General Psychology, 3(2), (1999), h. 101-117

28 Shuman, A. Entitlement and empathy in personal narrative. Journal, Narrative Inquiry, (2006). 16(1), h. 148

29 Zwaan, R. A. The immersed experiencer: toward an embodied theory of language comprehension. Journal, The Psychology of Learning, (2004), 44, h. 35-62

30 Hojat, M., Axelrod, D., Spandorfer, J., \& Mangione, S, Enhancing and sustaining empathy in medical students. Journal, Medical Teacher, (2013) (35), h. 996-1001

31 Sumadi Suryobroto, Psikologi Perkembangan, (Yogyakarta: Rake Press, 1984), h. 72 
Teori yang tertua adalah yang diajukan oleh psikolog Jerman Johan Friederische Herbart. Herbart berpendapat bahwa terjadinya pengembangan adalah oleh karena adanya unsur unsur yang berasosiasi, sehingga sesuatu yang bersifat simpel (unsur yang sedikit) makin lama makin banyak dan kompleks. ${ }^{32}$ Bahwa perkembangan naratif anak juga didasarkan pada perkembangan dirinya anak artinya anak pada mulanya sebelum berasosiasi dengan lainnya berinteraksi dengan lingkungan sekitarnya, anak tidak banyak mengalami perubahan karena adanya perubahan pada anak, disebabkan adanya stimulus dari luar dirinya.

Ahli-ahli yang mengikuti pendapat ini menyatakan bahwa apabila orang berbicara tentang perkembangan psikologis, maka ia hendaknya menggunakan hal hal psikologis sebagai landasan, bukan keadaan biologis atau keadaan keadaan lain. Tahap tahap perkembangan psikologis ini juga akan mempengaruhi perkembangan inteligensi pada anak artinya bahwa pada tahap tahap itu antara perkembangan psikologis dan emosi anak selalu mengiringi atau mempengaruhi dalam bersosialisasi terhadap lingkungannya. Pendapat tahap tahap perkembangan berdasarkan psikologis ini seperti yang diungkapkan oleh Piaget, mengasumsikan, berdasarkan perkembangan intelektual individu perkembangan dapat melewati empat frase:

1. Fase senso motorik, yang berlangsung dari umur 0,0 sampai umur 2,0.

2. Fase Pra oprasional dari umur 2,0 sampai 7,0

3. Fase operasional konkret yang berlangsung dari umur 7,0 sampai 12,0 .

4. Fase oprasional formal yang berlangsung sejak individu berumur $12,0.33$

Jika sebagai seorang instruktut atau pembimbing yang memaksakan pendiriannya sendiri dengan memakai kekerasan dan kekuasaan, maka individu akan mengalah dan tunduk kepada pendapat orang dewasa, sedangkan kemaunnya sendiri akan lenyap dan tidak berkembang.

31 Abu Ahmadi. Drs, Psikologi Perkembangan, (Jakarta, Rineka Cipta, 1991. h. 17

33 Ahmad Fauzi Op Cit, h. 83 
individu yang sedemikian itu nantinya akan menjadi individu yang tidak mempunyai inisiatif, imajinatif intelektual yang memadai dan tanpa kemauan dia akan terbiasa bersikap menunggu perintah, demikian juga perkembangan inteltual inteligensi akan mengalami penurunan karena ada tekanan dari yang lebih kuat atau yang menguasai.

Sebaliknya jika individu dituruti saja apa kehendaknya atau dibiarkan saja berbuat sesukanya, dengan maksud untuk menghindarkan perengketaan antara dia dengan orang dewasa, maka tindakan yang digambarkan itu hanya merupakan pengunduran sengketa saja yang nantinya akan timbul lagi yang lebih kuat. intelktual pada pengembangan ini jika ada stimulus yang longgar maka ia mengungkapkan atau bertindak sesuka hatinya, bahklan tanpa batas-batas tertentu.

Teori kebenaran mencakup:1) Kebenaran biasa; 2) Kebenaran Ilmu; 3) Kebenaran Filsafat; 4) Kebenaran Agama. ${ }^{34}$ Konsep teori kebenaran (Theory of Truth), yang dapat dikategorikan ke dalam beberapa jenis teori kebenaran di antaranya; Teori Kebenaran Korespondensi (The Correspondence theory of truth); 2.Teori Kebenaran Konsistensi (The coherence theory of truth); 3. Teori Kebenaran Pragmatis (The Pragmatic theory of truth). ${ }^{35}$ Konsepsi teori kebenaran lainya yaitu, Teori Kebenaran Berdasarkan Arti (Semantic Theory of Truth); 36

Berdasarkan uraian di atas dapat di analisis bahwa masalah kebenaran tidaklah sederhana, tingkatan-tingkatan/ gradasi berfikir akan menentukan kebenaran apa yang dimiliki atau diyakininya, demikian juga sifat kebenarannya juga berbeda. Hal ini menunjukan bahwa bila seseorang berbicara mengenai sesuatu hal, dan apakah hal itu benar atau tidak, maka pertama-tama perlu dianalisis tentang tataran berfikirnya, sehingga tidak serta merta menyalahkan

${ }^{34}$ Kattsoff, O, Louis, Pengantar Filsafat, (Yogyakarta: Tiara wacana Yogya., 2004), h. 45

35 Bakhtiar, Asmal, Filsafat Ilmu.Edisi revisi, (Jakarta: PT. Rajagrafika Persada, 2004), h. 16

36 Suriasumantri. S., Junjun, Filsafat Ilmu; Sebuah Pengantar Populer, Cetakan I, (Jakarta: Pustaka Sinar Harapan, 1988), h. 253 
atas sesuatu pernyataan, kecuali apabila pembicaraannya memang sudah mengacu pada tataran berfikir tertentu.

Berdasarkan kajian tentang jenis kebenaran dan teori kebenaran di atas, maka kriteria kebenaran dapat dinyatakan bahwa adanya kesesuaian antara suatu pernyataan dengan pernyataan lain sebelum yang diketahui, diterima, serta diakui; dan kemudian adanya kesesuaian antara pernyataan dengan fakta atau kenyataan.

Analisis filosofis kebenaran fiksi mengandung unsurunsur teori kebenaran: Teori Kebenaran Korespondensi (The Correspondence theory of truth), teori korespondensi menggunakan kriteria fakta, teori ini bisa disebut teori kebenaran empiris, Teori Kebenaran Konsistensi (The coherence theory of truth), teori konsistensi menggunakan dasar fikiran sebagai kriteria kebenaran rasional, Teori Kebenaran Pragmatis (The Pragmatic theory of truth), sebuah teori menggunakan kreteria nilai kegunaan sebagai kriteria kebenaran praktis. Adapun Teori Kebenaran Berdasarkan Arti (Semantic Theory of Truth), sebuah teori kebenaran menggunakan dasar kreteria makna sebagai simbol kebenaran.

Teori kebenaran fiksi dalam konteks korespondensi (The Correspondence theory of truth), sebagai kreteria fakta yang disebut dengan kebenaran empiris, bahwa pengarang mengemukakan hal itu berdasarkan pengalaman dan pengamatannya terhadap kehidupan. Namun, hal itu dilakukan secara selektif dan dibentuk sesuai dengan tujuannya yang sekaligus memasukkan unsur hubungan dengan penerangan terhadap pengalaman kehidupan manusia.

Teori kebenaran fiksi dalam konteks konsistensi (The coherence theory of truth) menggunakan dasar pemikiran kebenaran rasional, sebagai di ungkapkan oleh Nurgiyantoro, fiksi suatu karya dapat diartikan sebagai prosa naratif yang bersifat imajinatif, namun biasanya masuk akal dan mengandung kebenaran yang mendramatisasikan hubunganhubungan antar manusia. Fiksi menurut Altenbernd dan Lewis dapat diartikan sebagai prosa naratif yang bersifat imajinatif, tetapi biasanya masuk akal dan mengandung kebenaran yang mendramatisasi hubungan-hubungan antar manusia. 
Teori kebenaran fiksi dalam konteks pragmatis (The Pragmatic theory of truth), menggunakan dasar kreteria nilai kegunaan sebagai kebenaran langsung digunakan dalam praktek, bagi setiap person yang membaca cerita fiksi akan mengolah stimulus berupa pemikiran dan tindakan tokoh sehingga individu cenderung memahami dan mengaitkan dengan kejadian dan relasi dalam kehidupan sehari-hari.

Teori Kebenaran Berdasarkan Arti (Semantic Theory of Truth), menggunakan dasar makna sebagai simbol kebenaran, Cerita fiksi akan menampilkan berbagai masalah kehidupan manusia serta interaksinya dengan sesama manusia. Selain itu, cerita fiksi membuat kehidupan individu akan mampu berimajinasi, memahami situasi, pengalaman, dan emosi orang lain. Kemampuan empati individu akan meningkat setelah membaca cerita fiksi sehingga kemampuana imajinasi intelektual akan meningkat.

\section{b. Pengembangan Intelegensi}

Sering menemukan ada orang yang cepat, cekatan dan terampil dalam waktu yang relatif singkat dapat menyelesaikan tugas, pekerjaan yang dihadapinya. Begitu pula sebaliknya banyak orang dalam menyelesaikan tugas, masalah yang dihadapinya membutuhkan waktu yang relatif lama. Bahkan ada pula yang lamban dan tak dapat menyelesaikan pekerjaannya. Salah satu faktor yang menentukan hal tersebut adalah taraf intelegensi orang tersebut.

Intelegensi berasal dari bahasa inggris "intelligence "yang juga berasal dari bahasa latin yaitu "intellectus dan intelegentia atau intellegere". Teori tentang intelegensi pertama kali di kemukakan oleh spearman dan Wynn jones poll pada tahun 1951 Intelegensi berasal dari bahasa latin, yang berarti memahami. intelegensi adalah aktifitas atau perilaku yang merupakan perwujudan dari daya atau potensi untuk memahami sesuatu. ${ }^{37}$ Breckenridge dan Vincent berpendapat bahwa "intelegensi adalah kemampuan seseorang untuk belajar, menyesuaikan diri dan memecahkan masalah baru. ${ }^{38}$

37 Sumadi Suryabrata, Psikologi Pendidikan, (Jakarta: T. Raja Grafindo Persada, 2006), cet. I, h. 125

38 Anwar Prabu, Perkembangan Intelegensi Anak dan Pengukuran IQnya, (Bandung: Angkasa Bandung, 1993), h. 34 
Alan, menjelaskan pengertian dari crystallized intelligence dan fluid intelligence. Crystallized intelligence mengacu pada fungsi intelektual pada tugas-tugas yang menyerukan akulturasi, pencarian dan pelatihan sebelumnya, sedangkan fluid intelligence melibatkan pemecahan masalah dan penalaran di mana kuncinya adalah adaptasi dan fleksibilitas ketika dihadapkan dengan rangsangan asing. ${ }^{39}$ Sternberg mengungkapkan bahwa inteligensi adalah kapasitas untuk belajar dari pengalaman dengan menggunakan proses-proses metakognitif dalam upayanya meningkatkan pengetahuan, dan kemampuan untuk beradaptasi dengan lingkungan sekitar. Inteligensi mensyaratkan kemampuan adaptasi yang berbeda di dalam konteks-konteks sosial dan budaya yang berbeda. ${ }^{40}$

Istilah IQ diperkenalkan pertama kalinya pada tahun 1912 oleh seorang ahli psikologi berkebangsaan Jerman bernama William Stern (Gould 1981). Kemudian ketika Lewis Madison Terman, seorang ahli psikologi berkebangsaan Amerika di Universitas Stanford, menerbitkan revisi tes Binet di tahun 1916, istilah IQ mulai digunakan secara resmi. Desmita dalam buku Psikologi Perkembangan menjelaskan bahwa IQ adalah kemampuan berfikir secara abstrak, memecahkan masalah dengan menggunakan simbol-simbol verbal dan kemampuan untuk belajar dari dan menyesuaikan diri dengan pengalaman-pengalaman hidup sehari-hari. ${ }^{41}$

H. Goddard berpendapat yang dikemukakan oleh Saifuddin Anwar, Mendefinisikan intelegensi sebagai tingkat kemampuan pengalaman seseorang untuk menyelesaikan masalah-masalah yang langsung dihadapi dan untuk mengantisipasi masalah-masalah yang akan dating. ${ }^{42}$ Inteligensi dengan demikian dapat dinyatakan Intelegensi

39 Alan J. Rowe. Creative intelligence: Discovering the Innovative Potential in Ourselves and Others. (Bandung. Mizan, 2005), h. 78

40 Sternberg, R.J. Cognitive psychology, Fourth Edition, Psikologi kognitif. Yudi Santoso. (terj.). (Yogyakarta: Pustaka Pelajar, 2008), h. 73

41 Desmita, Psikologi Perkembangan, (Bandung: PT.Rosda Karya, 2006), h. 170.

42 Saifuddin Azwar, Psikologi Intelegensi, (Yogyakarta: Pustaka Pelajar, 2002), h. 5 
sebagai kemampuan untuk melihat hubungan yang relevan diantara objek-objek atau gagasan-gagasan, serta kemampuan untuk menerapkan hubungan-hubungan ini kedalam situasi-situasi yang serupa.

Kemampuan intelegensi terdapat skala taraf, dari taraf intelegensi yang tinggi sampai taraf intelegensi yang rendah. Pengembangan merupakan suatu seri perbuatan menurut aturan-aturan tertentu dari keadaan semula menuju keadaan yang lebih lengkap atau lebih matang. Pengembangan terjadi dengan teratur dimana tiap tingkat pengembangan mempunyai hubungan tertentu dengan tingkat berikutnya. Suatu terjadi pada tingkat pengembangann akan diteruskan pada tingkat berikutnya dan bahkan mmpengaruhi perkembangan pada tingkat berikutnya. Ada dua ciri ciri perubahan pokok dari pengembanagan yaitu: 1. Adanya penambahan ukuran/berat serta perbedaan perbandingan ukuran/berat dan keesanggupan. 2. Hilangnya ciri ciri ang lama dan munculnya ciri ciri yang baru. ${ }^{43}$

Dari segi fisik adanya pengembangan yang jelas artinya ada perubahan ukuran jasmani dari sebelumnya sejalan dengan bertambahnya umur. Ukuran badan akan bertambah besar baik yang tampak yaitu kaki, tangan, perut, kepala, tinggi badan dan lain lain dan yang tidak tampak yaitu: jantung, paru paru, ginjal dan lain lain. Dalam teori psikologi kepribadian esensi manusia sebagai subyek total dan aspek-aspeknya yang khas misalnya, seseorang itu bersifat emosional atau tidak emosional. ${ }^{44}$ Artinya teori kepribadian ini sebuah pikiran yang sistimatis, mengenai manusia sebagai individu, dan sebagai individu tentunya tidak akan terlepas dari aspek perkembangan jasmani (badan). Dalam segi kejiwaan mengalami perubahan yaitu bertambahnya kemampuan, kesanggupan, mengamati, menginggat, merasa dan sebagainya sejajar dengan pertumbuhan jasmani. Jiwa yang sehat akan berkembang sejalan dengan pertumbuhna jasmani yang sehat juga. Kalau semula anak egosentrisme lambat laun menjadi sosial. Sebagaimana pendapat William James yang dikenal dengan

43 Abu Ahmadi. Opcit, h. 95

44 Panut Panuju, Drs. Psikologi Kepribadian, (Fakultas Tarbiyah IAIN Raden Intan, 1987), h. 102 
teori Periperial tentang emosi, menyatakan bahwa persepsi atau suatu rangsangan memicu perubahan-perubahan pada organ periferal seperti (jantung, paruparu, isi perut dan sebgainya) .45

Berdasarkan gejala kejiwaan ini, prinsip tersebut digunakan sebagai dasar untuk kepentingan praktis yaitu diciptakan "Lie didektor" sebagai suatu alat yang digunakan dalam lapangan psikologi kriminal yang telah memberikan bantuan positif terhadap lapangan kriminalitas. Lie Didektor diciptakan atas dasar adanya hubungan antara emosi yang dialami individu dengan perubahan perubahan kejasmaniannya. Alat ini diciptakan oleh John A. Larson yang kemudian dismpurnakan oleh L.Keeler. ${ }^{46}$.Dengan alat ini perubahan perubahan yang terjadi pada jasmani dapat dicatat oleh alat tersebut.

Perubahan yang terjadi dalam membaca pada diri seseorang suatu aktivitas memahami informasi tertulis yang berguna dalam hidup bermasyarakat. Cerita fiksi adalah karya cerita imajinasi pengarang yang menampilkan keadaan dunia dan relasi antar manusia. ${ }^{47}$ Gibson mengemukakan aktivitas cerita fiksi dalam batas ilmu psikologi kognitif. Individu melakukan proses berpikir untuk mengolah informasi dari teks bacaan. Ketika membaca, pembaca menganalisis informasi, memisahkan informasi yang tidak relevan, dan memperhatikan hal-hal penting dalam teks. ${ }^{48}$

Fiksi sebagai karya sastra sebagai objek yang dianalisis, dianggap sebagai sesuatu yang menampilkan kualitas estetis yang paling beragam. Hakikat bahasa sebagai medium

${ }^{45}$ Adam Kuper dan Jessica Kuper, Ensiclopedi Ilmu Ilmu Sosial, Edisi ke 2, Raja Grafindo Persada, Jakarta 2000. Diterjemahkan dari buku asli, The Sosial Science Encyclopedia, Oleh . Haris Munandar, Aris Ananda, Meri J, Binsar, Yanto mustofa dan Triwibowo Budi Santoso. h. 228 h. 78

${ }^{46}$ Bimo Walgito Op Cit. h. 135

${ }^{47}$ Stanton, Robert. Teori Fiksi, (Yogyakarta: Pustaka Pelajar, 2007),

${ }^{48}$ Gibson, J.L., Ivancevich, J.M., dan Donnelly, J.H., Organizations: Behavior, Structure, Processes, (Chicago: IRWIN, 1997), h. 29 
menyebabkan hadirnya berbagai mediasi sehingga melahirkan berbagai aspek estetis. Terjadinya keindahan itu diakibatkan oleh kemampuan penerima untuk menikmatinya. ${ }^{49}$

Sering pula sastra yang terbit setelah itu mempunyai fungsi hiburan belaka, walaupun bermutu kurang baik, tetap dinamakan sebagai sastra populer atau sastra pop. Sastra populer adalah perekam kehidupan, dan tidak banyak memperbincangkan kembali kehidupan dalam serba kemungkinan. Ia menyajikan kembali rekaman-rekaman kehidupan itu dengan harapan pembaca akan mengenal kembali pengalaman-pengalamannya sehingga merasa terhibur karena seseorang telah menceritakan pengalaman-pengalamannya. ${ }^{50}$ Sastra populer bersifat artifisial atau bersifat sementara, cepat ketinggalan zaman, dan tidak memaksa orang untuk membacanya sekali lagi, oleh karena itu, sastra populer cepat dilupakan pembacanya apalagi dengan munculnya karya sesudahnya. ${ }^{51}$

Wolfgang Iser dalam bukunya The Act of Reading: A Theory of Aesthetic Response mengemukakan bahwa teks memiliki arti ketika ia dibaca. Oleh karena itu, membaca menjadi prasyarat penting bagi proses interpretasi sastra. Titik sentral dalam pembacaan karya sastra adalah interaksi antara struktur karya tersebut dengan penerima atau pembaca. Tidak akan mungkin untuk mendeskripsikan tanggapan pembaca tanpa menganalisis proses pembacaannya. Dalam hal ini, analisis pembacaan terhadap teks menjadi sesuatu yang amat penting merujuk pada model pendekatan pragmatis. ${ }^{52}$ Di dalam membaca anak memerlukan bantuan dari benda benda sebagai alatnya, sedangkan

49 Murtono. "Resepsi Sastra: Analisis Sastra dari Sudut Pandang Pembaca" Journal Mawas. Kudus: Universitas Muria Kudus. Juni 2010, h. 9

50 Kayam, Umar, Seni, Tradisi, dan Masyarakat, (Jakarta: Sinar Harapan, 1981), h. 82

51 Nurgiyantoro, Burhan, Teori Pengkajian Sastra, (Bulaksumur: Gadjah Mada University Press, 1988), h. 20

52 Iser, Wolfgang. 1976. The Act of Reading: A Theory of Aesthetic Response, (Baltimore: Johns Hopkins UP, 1976), h. 34 
orang dewasa membaca tidak selalu memerlukan bantuan dari benda-benda, 53

Membaca sastra maupun meninterprestasi sastra memerlukan imajinasi dan inteligensi sebagai kemampuan memecahkan masalah dan kemampuan untuk beradaptasi dan berkreasi dari pengalaman sehari-hari. Lalu Ormrod (2009) menambahkan bahwa inteligensi merupakan kemampuan menerapkan pengetahuan dan pengalaman sebelumnya secara fleksibel untuk menghadapi tugas-tugas baru yang menantang. ${ }^{54}$ Sedangkan Wade dan Tavris mendefinisikan inteligensi sebagai suatu karakteristik dalam diri seseorang yang didapatkan melalui penalaran, umumnya didefinisikan sebagai suatu kemampuan untuk mengambil keuntungan dari suatu pengalaman, memperoleh pengetahuan, berpikir secara abstrak, bertindak berdasarkan alasan, atau beradaptasi terhadap perubahan yang terjadi pada lingkungan. 55

Kemampuan intelektual merupakan ekspresi dari apa yang disebut intelegensi dan kepada kemampuan intelek ini juga kita bersanda dalam menguasai dan memperlakukan perubahan kebudayaan serta pembaruan teknologi ini di masyarakat. Menurut Conny Semiawan, intelegensi adalah sebagai hasil perkembangan semua fungsi otak manusia. ${ }^{56}$

Inteligensi mencakup kemampuan untuk pemahaman terhadap hubungan yang kompleks, semua proses yang terlibat dalam berpikir abstrak, kemampuan penyesuaian

53 Agus Sujanto, Psikologi Perkembangan, Aksara Baru, Jakarta 1980. h. 28

${ }^{54}$ Ormrod, J.E. Educational psychology developing learners, Psikologi pendidikan membantu siswa tumbuh dan berkembang. Jilid 1 . Wahyu Indianti, Eva Septiana, Airin Y. Saleh \& Puji Lestari. (terj.).2009. (Jakarta: Erlangga, 2009), h. 19

${ }^{55}$ Wade, Sa. C dan Tavris, C. Educational Psychology, Pendidikan Psikologi. Mursalin \& Dianastuti (terj.).2007.Jakarta: Erlangga. ntrock, J.W. (2006). Educational psychology, (New York: McGraw-Hill, 2006), h. 78

${ }^{56}$ Semiawan, Prof. Dr. Conny R., Belajar dan Pembelajaran Prasekolah dan Sekolah Dasar (Jakarta Barat: PT. Indeks 2008), h. 11.

Pengembangan intelegensi sebagai kombinasi sifat-sifat manusia yang 
dalam pemecahan masalah dan kemampuan untuk memperoleh kemampuan baru. Manusia memiliki kemampuan luar biasa untuk meningkatkan diri sendiri, dengan menggunakan kemampuannya. Inteligensi sebagai kemampuan untuk bertindak secara terarah, berpikir secara rasional dan menghadapi lingkungannya. ${ }^{57}$

Berdasarkan uraian tersebut dapat di analisis bahwa suatu kemampuan yang dibawa oleh individu sejak lahir dan dapat dipergunakan untuk menyesuaikan diri dengan lingkungan serta untuk memecahkan masalah-masalah yang dihadapi dengan cepat dan tepat. Karena itu, inteligensi tidak dapat dikembangkan, melalui proses berfikir secara konvergan menyebar menyeluruh untuk meningkatkan kemampuannya baik dari segi kognitif afektif dan kemudian melalui tindakan nyata yang merupakan manifestasi dari proses berpikir rasional.

Inteligensi tinggi ditandai dengan ingatan yang kuat, dan inteligensi yang tinggi (daya tangkapnya) melalui latihan dan pembiasaan proses berfikir dan memudahkan individu memperoleh pengetahuan dan memahami berbagai ilmu. Daya tangkap yang kurang merupakan dasar pada seorang individu. ${ }^{58}$

Asumsi tersebut dapat dipahami bahwa inteligensi atau suatu kecerdasan pemikiran daya menyesuaikan diri dengan keadaan baru dengan menggunakan alat-alat berpikir menurut tujuannya. Masalah inteligensi secara cerdas penyesuaian diri terhadap masalah yang dihadapinya. Pada orang yang inteligen akan lebih cepat dalam menyelesaikan masalahmasalah baru apabila dibandingkan dengan orang yang kurang inteligen. Dalam menghadapi masalah atau situasi baru orang yang inteligen akan cepat dapat mengadakan adjustment terhadap masalah atau situasi yang baru tersebut.

57 Lucy, Bunda \& Rizky, Ade Julius. 2012. Dahsyatnya Brain Smart Teaching: Cara Super Jitu Optimalkan Kecedasan Otak Anak., (Jakarta: Penebar Plus, 2012), h. 51

58 As'adi, Muhammad, Bila Otak Kanan dan otak kiri Seimbang, (Jogjakarta: Diva Press, 2010), h. 51 
Pengembangan (development) inteligensi dalam psikologi merupakan sebuah konsep yang dengan menggunakan daya nalar, di dalamnya terkandung banyak dimensi di antaranya adalah pertumbuhan, perkembangan, kematangan, dan perubahan. Seifert dan Hoffnung pengembangan sebagai Long-term changes in a person's growth feelings, paterns of tingking, social relationships, and motor skills. 59 Pengembangan sebagai proses ke arah yang lebih sempurna dan tidak dapat terulang kembali. Pengembangan pada perubahan yang bersifat tetap dan tidak dapat diputar kembali. Pengembangan sebagai proses yang kekal dan tetap menuju ke arah suatu keadaan pada tingkat integrasi yang lebih tinggi. ${ }^{60}$ Pengembangan tidak terbatas pada pengertian perubahan secara fisik, melainkan di dalamnya juga terkandung serangkaian perubahan secara terus menerus dari fungsi-fungsi jasmaniah dan rohaniah yang dimiliki individu menuju tahap kematangan. ${ }^{61}$ Pengembangan sebagai kecenderungan untuk mengaktualisasi diri, mewujudkan potensi, dorongan untuk menjadi matang, dalam upaya mengekspresikan diri dan mengaktifkan semua kemampuan organisme secara keseluruhan. ${ }^{62}$ Howard Gardner pengembangan mempunyai dua aspek, yakni kapasitas dan keinginan untuk menjadi inovatif dan penerimaan akan inovasi. ${ }^{63}$ Pengertian Pengembangan, merupakan proses atau langkah-langkah untuk mengembangan suatu objek baru atau menyempurnakan objek yang telah ada, agar lebih menyebar dan berkelanjutan mengikuti perkembangan ilmu

59 Seifert, K.L. dan Hoffnung, R.J., Child and Adolescent Development, (Boston: Houghton Mifflin Company, 1994), h. 17

${ }^{60}$ Monks F.J. A.M.P Knoers, Ontwikkelings Psychology, terj. Siti Rahayu Haditono, (Yogyakarta: Gadjah Mada University Press, 1998), cet. 11, h. 1

61 Desmita, Psikologi Perkembangan, (Bandung: PT. Remaja Rosda Karya, 2005), h. 4

62 Anna Craf. Creativity Across the primary Curiculum, London, 2000, di terjemhkan oleh M. Charul Annam, dengan judul, Membangun Kreativitas Anak, (Jakarta: Inisiasi Press, 2003), h. 47

${ }^{63}$ Daniel Fung dan Cai Yi-Ming, Raise Your Child Raight, 2002 di terjemahkan oleh Commec dengan judul, Mengembangkan Kepribadian Anak dengan Tepat, (Jakarta: Prestasi Pustaka, 2003), h. 63 
dengan dipadukan oleh unsur-unsur modern dan teknologi ${ }^{64}$ Pengembangan sebagai bentuk sistematis, bertujuan untuk diarahkan kemudian mencaritemukan, merumuskan, memperbaiki, meperbaharui, menghasilkan, kualitas yang lebih unggul dan produktif. ${ }^{65}$

Berdasarkan asumsi tersebut di atas maka sebuah pengembangan inteligensi dimulai dengan pencarian gagasan dan pemikiran berupa inovasi imajinasi untuk mendiskripsikan gambaran objek dengan tujuan agar objek tersebut dapat dipadukan dalam dunia realitas. Kecenderungan tersebut dimaknai dengan sebuah inovasi untuk mewujudkan potensi yang berkelanjutan yang dapat menghasilkan kualitas yang produktif. Konsepsi pengembangan inteligensi dalam kerangka memperkaya dan membaca sebuah inspirasi, imajinasi dan daya kreatif sehingga dapat menambah pengetahuan bagi pembacanya dan memberikan kemudahan untuk dapat menganalisis fenomena yang di pahami.

Intelegensi sebagai sesuatu yang merupakan interaksi aktif antara kemampuan yang dibawa sejak lahir dengan pengalaman yang diperoleh dari lingkungan yang menghasilkan kemampuan individu untuk memperoleh, mengingat dan menggunakan pengetahuan. Mengerti makna dari konsep konkrit dan konsep abstrak, dan dapat menghubungkan yang ada diantara objek, peristiwa, ide dan kemampuan dalam diterapkan. 66

Konsepsi tersebut dapat dianalisis bahwa teori intelegensi tersebut berbicara seputar kemampuan belajar individu terhadap objek yang dihadapi kemudian dipahami serta menganalisis dan menjabarkan dari objek tersebu. Kemudian memperoleh pengetahuan yang di peroleh atau dikatakan epistemology bahwa bagaimana sebuah pengetahuan

64 Prof. Dr. Nana Syaodih Sukmadinata, 2005,Landasan Psikologi Proses Pendidikan, (Bandung: PT Rosda Karya, 2005), h. 164

65 Putra, Nusa. 2011. Researchand development Penelitian dan pengembangan: suatupengantar, (Jakarta: Rajagrafindo Persada, 2011), h. 67

66 Jamaris Martini, Orientasi Baru dalam Psikologi Pendidikan, (Jakarta:Yayasan Penamas Murni, 2010), h. 2 
diperoleh, melalui pengalaman yang disebut empirisme, melalui akal fikiran yang dinamakan rasionalisme, mengandung unsur langsung dikerjakan dinamakan pragmatis, kemudian dapat mengamati objek fenomena atau di katakana fenomenologi. Seseorang yang mampu beradaptasi atau mempunyai kemampuan beradaptasi dengan sesuatu yang baru dan meresponya dalam inteligensi yang nantinya dapat dijadikan dasar untuk berfikir.

Atas dasar konseptualisasi bahwa intelegensi itu sebagai kemampuan menghadapi dan menyesuaikan diri terhadap situasi baru secara cepat dan efektif dan berguna. Inteligensi sebagai sebuah kecerdasan untuk menetapkan dan mempertahankan tujuant tertentu. Semangkin cerdas seseorang akan semangkin cakap dia membuat tujuan sendiri, mempunyai inisiatif sendiri tidak menunggu perintah. Kemampuan untuk melakukan otokritik, kemampuan untuk menganalisis dan mengkaji.

Fluid intelligence sebuah konsepsi kemampuan analisis kognitif yang relatif tidak dipengaruhi oleh pengalaman mengkaji sebelumnya, Crystallized intelegence yaitu keterampilan-keterampilan atau kemampuan nalar (berpikir) yang dipengaruhi oleh pengalaman memperoleh pengetahuan. ${ }^{67}$ Bentuk kreasi yang memungkinkan manusia meningkatkan kualitas hidupnya, berupa ide-ide baru, penemuan-penemuan baru, dan teknologi baru. Dalam pengembangannya mencapai hal itu perlulah sikap pemikiran dan perilaku kreatif, imajinatif, inovatif yang akan menunjang kemampuanan inteligensi. 68

Berdasarkan argumentasi di atas, konsepsi intelegensi sebuah pengertian mengenai kreativitas dari pokok bahasan di dalami, dipahami, di analisi secara mendalam, maka akan jelas terlihat terdapat hubungan fenomena maupun realitas dari sebuah ilmu pengetahuan. Sebab imajinasi inteligensi akan menjurus kepada kepenciptaan sesuatu yang baru bergantung pada kemampuan untuk mendapatkan penge-

67 Yusuf LN Syamsu, Psikologi Perkembangan Anak dan Remaja, (Bandung: Roesdakarya, 2012), h. 97

68 Munandar Utami, 2012, Pengembangan Kreativitas Anak Berbakat, (Jakarta: Rineka Cipta, 2012), h. 23 
tahuan yang diterima. Pengetahuan tersebut kemudian diatur dan diolah ke dalam bentuk baru dan orisinal, seseorang akan menggunakan pengetahuan yang diterima sebelumnya dan ini bergantung terhadap kemampuan intelektual seseorang.

Pengembangan inteligensi pada kebenaran fiksi terhadap kehidupan individu manusia sebagaimana pendapat Guilford bukan pada pengembangan inteligensi cara berpikir konvergen (memusat), akan tetapi lebih kepada cara berpikir divergen (menyebar). Argumentasi tersebut di perkuat oleh Utami Munandar yang menjelaskan bahwa berpikir divergen (yang juga disebut berpikir imajinatif kreatif) sebuah kemampuan memberikan bermacam-macam jawaban berdasarkan informasi yang diberikan, dengan penekanan pada keragaman, jumlah dan kesesuaian. Pengembangannya mencapai hal itu perlulah sikap pemikiran dan perilaku kreatif, imajinatif, inovatif yang akan menunjang kemampuanan inteligensi seseorang individu. Inteligensi dalam dalam karya fiksi merupakan sebuah konsep yang dengan menggunakan daya nalar, di dalamnya terkandung banyak dimensi di antaranya adalah pertumbuhan, perkembangan, kematangan, dan perubahan, karya fiksi tersebut yang akan mempengaruhi kehidupan cara berfikir, berimajinasi, daya nalar pengaruhnya bagi manusia.

\section{Kesimpulan}

Filosofis kebenaran fiksi dapat diartikan sebagai prosa naratif yang bersifat imajinatif, dan biasanya dapat masuk akal sebab, mengandung kebenaran yang mendramatisasi hubunganhubungan antar manusia. kebenaran fiksi berdasar atas pengalaman dan pengamatannya terhadap kehidupan. Namun, hal itu dilakukan secara selektif dan dibentuk sesuai dengan tujuannya yang sekaligus memasukkan unsur hubungan dengan penerangan terhadap pengalaman kehidupan manusia.

Intelegensi dalam fiksi atau karya fiksi sebagai sesuatu yang merupakan interaksi aktif atas kemampuan yang dibawa oleh individu manusia dengan pengalaman yang diperoleh dari lingkungan yang menghasilkan kemampuan daya nalar untuk memperoleh, mengingat dan menggunakan pengetahuan. 
Mengerti makna sebuah fiksi dari suatu konsep abstrak ke realitas konkrit, serta dapat menghubungkan yang ada diantara objek, peristiwa, ide dan kemampuan daya kecerdasan.

Pengembangan inteligensi pada kebenaran fiksi terhadap kehidupan individu manusia dengan melalui cara berpikir dengan konsep divergen (yang juga disebut berpikir imajinatif kreatif) sebuah kemampuan memberikan bermacam-macam jawaban berdasarkan informasi yang diberikan, dengan penekanan pada keragaman, tersebut yang akan mempengaruhi kehidupan cara berfikir, berimajinasi, daya nalarnya. Pengembangannya mencapai hal itu perlulah sikap pemikiran dan perilaku kreatif, imajinatif, inovatif yang akan menunjang kemampuanan inteligensi seseorang individu.

\section{Daftar Pustaka}

Abu Ahmadi. Drs, Psikologi Perkembangan, Jakarta,Rineka Cipta, 1991.

Adam Kuper dan Jessica Kuper, Ensiclopedi Ilmu Ilmu Sosial, Edisi ke 2, Raja Grafindo Persada, Jakarta 2000.Di terjemahkan dari buku asli, The Sosial Science Encyclopedia, Oleh. Haris Munandar, Aris Ananda, Meri J, Binsar, Yanto mustofa dan Triwibowo Budi Santoso.

Agus Sujanto, Psikologi Perkembangan, Aksara Baru, Jakarta 1980.

Ahmad Fauzi. Drs.H, Psikologi Umum, Bandung: Pustaka Setia, 1999.

Alan J. Rowe. Creative intelligence: Discovering the Innovative Potential in Ourselves and Others. Bandung. Mizan, 2005.

Altenbernd, Lynn dan Lewis. 1966. A Handbook for The Study of Poetry, New York: Macmillan, 1966.

Anna Craf. Creativity Across the primary Curiculum, London, 2000, di terjemhkan oleh M. Charul Annam, dengan judul, Membangun Kreativitas Anak, Jakarta: Inisiasi Press, 2003.

Anwar Prabu, Perkembangan Intelegensi Anak dan Pengukuran IQnya, Bandung: Angkasa Bandung, 1993.

As'adi, Muhammad, Bila Otak Kanan dan otak kiri Seimbang, Jogjakarta: Diva Press, 2010. 
Bakhtiar, Asmal, Filsafat Ilmu.Edisi revisi, Jakarta: PT. Rajagrafika Persada, 2004.

Bakker, Anton dan Achmad Charris Zuberi, Metodologi Penelitian Filsafat, Yogyakarta: Kanisisus, 1990.

Bakker, Anton, Metode-Metode Filsafat, Jakarta, Ghalia Indonesia, 1984.

Bimo Walgito, Drs.H. Psikologi Umum, Yogyakarta: Fakultas Psikologi UGM, 1981.

Daniel Fung dan Cai Yi-Ming, Raise Your Child Raight, 2002 di terjemahkan oleh Commec dengan judul, Mengembangkan Kepribadian Anak dengan Tepat, Jakarta: Prestasi Pustaka, 2003.

Desmita, Psikologi Perkembangan, Bandung: PT.Rosda Karya, 2006.

Desmita, Psikologi Perkembangan, Bandung: PT. Remaja Rosda Karya, 2005.

Faruk, Pengantar Sosiologi Sastra. Yogyakarta: Pustaka Pelajar, 1999.

Gibson, J.L., Ivancevich, J.M., dan Donnelly, J.H., Organizations: Behavior, Structure, Processes, Chicago: IRWIN, 1997.

Haris, Herdiansyah, 2012. Metodologi Penelitian Kualitatif Untuk Ilmu-Ilmu Sosial, Jakarta Selatan: Salemba Humanika, 2012.

Hasan Langgulung, Prof. DR., Asas Asas Pendidikan Islam, Jakarta: Al Husna Zikra, 2002.

Hojat, M., Axelrod, D., Spandorfer, J., \& Mangione, S, Enhancing and sustaining empathy in medical students. Journal, Medical Teacher, 2013.

Iser, Wolfgang. 1976. The Act of Reading: A Theory of Aesthetic Response, Baltimore: Johns Hopkins UP, 1976.

Jamaris Martini, Orientasi Baru dalam Psikologi Pendidikan, Jakarta:Yayasan Penamas Murni, 2010.

Kaelan, Metodologi Penelitian Kualitatif bidang Filsafat, Yogyakarta: Paradigma, 2006.

Kattsof, O. Louis, Pengantar Filsafat, Yogyakarta: Tiara Wacana Yogya, 1996, Judul Asli: Elements of Philosophy, North 
Carolina University U.S.A. The Ronald Press Company New York. Alih Bahasa Soejono Soemargono.

Kattsoff, O, Louis, Pengantar Filsafat, Yogyakarta: Tiara wacana Yogya., 2004.

Kayam, Umar, Seni, Tradisi, dan Masyarakat, Jakarta: Sinar Harapan, 1981.

Kuswarno, Engkus, Metodelogi Penelitian, Konsepsi, Pedoman dan Contoh Penelitian, Bandung: Widia Padjajaran, 2009.

Lucy, Bunda \& Rizky, Ade Julius. 2012. Dahsyatnya Brain Smart Teaching: Cara Super Jitu Optimalkan Kecedasan Otak Anak, Jakarta: Penebar Plus, 2012.

Monks F.J. A.M.P Knoers, Ontwikkelings Psychology, terj. Siti Rahayu Haditono, Yogyakarta: Gadjah Mada University Press, 1998.

Munandar Utami, 2012, Pengembangan Kreativitas Anak Berbakat, Jakarta: Rineka Cipta, 2012.

Murtono. "Resepsi Sastra: Analisis Sastra dari Sudut Pandang Pembaca" Journal Mawas. Kudus: Universitas Muria Kudus. Juni 2010.

Nazir, Metode Penelitian Kualitatif, Jakarta: Ghalia Indonesia, 1988.

Noor, J., Metodologi Penelitian Skripsi, Tesis, Desertasi, dan Karya Ilmiah, Jakarta: Kencana, 2011.

Nurgiyantoro, Burhan. 2013. Sastra Anak: Pengantar Pemahaman Dunia Anak. Yogyakarta: Gadjah Mada University Press, 2013.

Nurgiyantoro, Burhan, Teori Pengkajian Fiksi, Yogyakarta: Gadjah Mada University Press, 2009.

Nurgiyantoro, Burhan, Teori Pengkajian Fiksi, Yogyakarta: Gajah Mada University Press, 2010.

Nurgiyantoro, Burhan, Teori Pengkajian Sastra, Bulaksumur: Gadjah Mada University Press, 1988.

Oatley, K. Mar dan Peterson, Why fiction may be twice as true as fact: fiction as cognitive and emotional simulation. Journal, Review of General Psychology, 3(2), 1999. 
Ormrod, J.E. Educational psychology developing learners, Psikologi pendidikan membantu siswa tumbuh dan berkembang. Jilid 1. Wahyu Indianti, Eva Septiana, Airin Y. Saleh \& Puji Lestari. (terj.).2009. Jakarta: Erlangga, 2009.

Panut Panuju, Drs. Psikologi Kepribadian, Fakultas Tarbiyah IAIN Raden Intan, 1987.

Prof. Dr. Nana Syaodih Sukmadinata, 2005,Landasan Psikologi Proses Pendidikan, Bandung: PT Rosda Karya, 2005.

Purba, Antilan, Sastra Indonesia Kontemporer, Yogyakarta: graha Ilmu, 2010.

Putra, Nusa. 2011. Researchand development Penelitian dan pengembangan: suatu pengantar, Jakarta: Rajagrafindo Persada, 2011.

Saifuddin Azwar, Psikologi Intelegensi, Yogyakarta: Pustaka Pelajar, 2002.

Seifert, K.L. dan Hoffnung, R.J., Child and Adolescent Development, Boston: Houghton Mifflin Company, 1994.

Semiawan, Prof. Dr. Conny R., Belajar dan Pembelajaran Prasekolah dan Sekolah Dasar, Jakarta Barat: PT. Indeks 2008.

Shuman, A. Entitlement and empathy in personal narrative. Journal, Narrative Inquiry, 2006.

Soetriono dan SRDm Rita Hanafi, Filsafat Ilmu dan Metodologi Penelitian, Yogyakarta: Andi offset, 2007.

Stanton, R, Teori Fiksi, Yogyakarta: Pustaka Pelajar, 2007.

Stanton, Robert. Teori Fiksi,(Yogyakarta: Pustaka Pelajar, 2007.

Sternberg, R.J. Cognitive psychology, Fourth Edition, Psikologi kognitif, Yudi Santoso. (terj.), Yogyakarta: Pustaka Pelajar, 2008.

Sugiyono, Metode Penelitian Kuantitatif, Kualitatif, Bandung: Alfabeta, 2009.

Sumadi Suryabrata, Psikologi Pendidikan ,Jakarta :T. Raja Grafindo Persada, 2006.

Sumadi Suryobroto, Psikologi Perkembangan, Yogyakarta: Rake Press, 1984. 
Suriasumantri. S., Junjun, Filsafat Ilmu; Sebuah Pengantar Populer, Cetakan I, Jakarta: Pustaka Sinar Harapan, 1988.

Syaiful Bahri, Psikologi, Jakarta: Rineka Cipta: 2011.

Utami Munandar, Pengembangan Kreativitas Anak Berbakat, Jakarta: Rineka Cipta, 1999.

Wade, Sa. C dan Tavris, C. Educational Psychology, Pendidikan Psikologi. Mursalin \& Dianastuti (terj.). 2007. Jakarta: Erlangga. ntrock, J.W. 2006. Educational psychology, (New York: McGraw-Hill, 2006.

Woodworth, Robert S And Marquis D.G, Psikologi, Henry Hold and Company New York, 1957.

Yusuf LN Syamsu, Psikologi Perkembangan Anak dan Remaja, Bandung: Roesdakarya, 2012.

Zuchdi, D, Strategi Meningkatkan Kemampuan Membaca Peningkatan Komprehensi, Yogyakarta: UNY Press, 2008.

Zwaan, R. A. The immersed experiencer: toward an embodied theory of language comprehension. Journal, The Psychology of Learning, 2004. 